\title{
ASEAN CORPORATE GOVERNANCE SCORECARD, FINANCIAL PERFORMANCE, AND DISCLOSURE OF CORPORATE SOCIAL RESPONSIBILITY ON FIRM VALUE
}

\author{
Rista Bintara \\ Accounting Study Program, \\ Faculty of Economics and Business, \\ Mercu Buana University \\ Jl. Raya Meruya Selatan Kembangan \\ West Jakarta Indonesia,
}

Article DOI: https://doi.org/10.36713/epra4799

\begin{abstract}
The objectives of this study are as follows: 1) To examine the ASEAN Corporate Governance Scorecard on firm Value; 2) To review the Financial Performance on firm Value; and 3) To examine the effect of Corporate Social Responsibility Disclosure on firm Value. This type of research used in this study is a casual associative research (causal associative research). The population in this study are companies included in the TOP 50 ASEAN Corporate Governance Scorecards listed on the Indonesia Stock Exchange in the period 2015-2017. Sample selection with purposive sampling method. The analytical method used to test hypotheses is the multiple regression test. The results showed that: 1) The ASEAN Corporate Governance Scorecard variable did not affect the firm value in a positive direction; 2) Profitability variable has a positive effect on firm value; 3) Variable disclosure of Corporate Social Responsibility does not affect the firm value with a negative direction.
\end{abstract}

KEYWORDS: ASEAN Corporate Governance Scorecard, Financial Performance, Corporate Social Responsibility, Firm Value

\section{INTRODUCTION}

The business world has increasingly developed at this time. The emergence of various companies both small and large is a common phenomenon. This phenomenon causes the level of competition between companies to become increasingly stringent. Competition for companies can have a positive effect, namely the drive to always improve the quality of the products produced, but competition also has a negative impact on the company, ie their products will be displaced from the market if the company fails to improve the quality and quality of the products produced. In addition, mastery of technology and communication skills are also needed to continue to survive in the business world today and in the future. With the increasingly intense competition in this globalization era, increasing high company value is a long-term goal that should be achieved by the company which will be reflected in the market price of its shares because investor valuation of the company can be observed through the movement of stock prices of companies traded on the stock exchange for companies that have gone public .

Investors in investing their wealth in an investment instrument is to get the maximum return. Therefore, investors must have various considerations before investing their funds. One way is to consider the company's performance as measured by the company's value. Company value can be measured from various aspects including market value (book value) and book value of equity. Equity market value is the value of equity based on market prices associated with the company's stock price in the capital market, while the book value of equity is the value of equity based on the company's books.

Measurement of company value based on market value of equity and book value has weaknesses. Brown and Caylor (2006 in Sumatriani, 2017) state that measurement of company value based on stock market prices has weaknesses. First, there are elements of the game played by speculators 
to get relatively short profits from the stock market price can go up or down (dramatically). Second, stock market prices tend to be influenced by psychological pressure or irrational actions of investors in investing. Furthermore Brown and Caylor (2006 in Sumatriani, 2017) also stated that the weakness of book value is that it allows for the practice of manipulating financial transactions and as a basis for management to manage earnings to achieve predetermined profit targets. Therefore, investors can consider other company performance measurements.

One measurement of company performance that can be used is to combine book value and market value of equity through the Tobin's $Q$ ratio. This ratio is measured from the market value of assets divided by the book value of assets. Tobin's Q is a more rigorous measure because it provides an overview not only of the fundamental aspects, but also the extent to which the market evaluates the company from various aspects seen by outsiders including investors (Gregory et al., 2007 in Sumatriani, 2017).

To improve the achievement of company goals, the improvement of services and supervision mechanisms need to be improved through the application of corporate governance. The implementation of corporate governance is expected to be a barrier to management fraud behavior, so that the company's performance report (company value) illustrates the true fundamental value. In addition it can create organizational performance that is transparent, accountable, responsible, and reasonable so that it can increase the value of the company.

Research on the effect of good corporate governance on corporate value in developing countries, namely Malaysia, was conducted by (Bhatt \& Bhatt, 2017) using the Malaysian Corporate Governance Index (MCGI). The results of this study indicate that companies with high corporate governance have better performance. The results of the study are in line with research (Owusu \& Weir, 2016) in Ghana that uses the Ghananian Corporate Governance Index (GCGI) to assess Corporate Governance. The results of this study indicate that there is a significant positive relationship between the Ghananian Corporate Governance Index (GCGI) and company performance. In Indonesia research with this theme was carried out by Adhiprasetya \& Zulaikha (2019). The study examines companies that are included in the Corporate Governance Perception Index (CGPI) ranking. The results of the study concluded that the ranking of the Corporate Governance Perception Index (CGPI) had no significant effect on firm value. But unlike previous studies, research (Halim \& Christiawan, 2017) shows that the Corporate Governance Perception Index (CGPI) has a significant impact on company performance.

Besides being influenced by the implementation of corporate governance, corporate value can also be influenced by profitability. Profitability is the ability of a company to operate in the long run which depends on obtaining an adequate level of profit (Pearce and Robinson, 2008). To assess profitability, you can use benchmarks such as ratios or indexes that connect two financial data in the financial statements. An assessment of profitability can also be seen by analyzing financial ratios. For this reason, researchers use financial ratios to see the condition of a company. The financial ratio that is often used in analyzing profitability is Return on Assets (ROA) which illustrates the extent of the ability of assets owned by the company can generate profits

Leonardo \& Khairunnisa (2019), and Susanti, et al (2019) found that financial performance had a significant positive effect on firm value. While research Lutfia, et al (2019), Lastanti \& Salim (2019) found that financial performance had no effect on firm value.

CSR disclosure can increase company value. This is based on research by Alshammari (2015), companies that implement CSR will show better performance, and profit and company growth is increasing. One of the literature shows that companies that act responsibly in their social context can gain competitive advantage and therefore increase the value of their companies. But there are still conflicting findings, such as (Williamdan Siegel, 2001 in Sumatriani, 2017) providing a record of the optimal level of Corporate Social Responsibility for managers to be the basis of controlling an economic view of costs and benefits, CSR does not have a significant impact on firm value. Anderson and Olsen (2011) found a strong relationship between CSR levels and firm value.

The implementation of CSR can be seen from the disclosures made by the company both in the annual report (annual report) and in the report. which is separate from the annual report. CSR disclosures provide information to stakeholders regarding the existence of existing social contracts between companies and stakeholders and company compliance with regulations established by the government (Garcia et al., 2009).

The company carries out CSR activities to balance corporate growth and social commitment, by optimizing company value and social performance. Furthermore CSR resource-based view, states that CSR actions have an impact on stakeholders, CSR investments are relatively related to corporate and social values, because companies can reduce transaction costs by using social activities related to stakeholders (Yongtao and Magaret, 2011).

Mukhtaruddin et al. (2019), and Safira \& Saifi (2019) found that the disclosure of Corporate Social Responsibility affects the value of the company. While the research of Sumantri \& Andini (2019) found that the disclosure of Corporate Social Responsibility does not affect the value of the company.

Based on the description above, the authors are interested in conducting research entitled "ASEAN Corporate Governance Scorecard, Financial 
Performance, and Disclosure of Corporate Social Responsibility On Firm Value".

From the description of the research background above, the main issues to be formulated for discussion in this study can be formulated, namely: 1) Does the ASEAN Corporate Governance Scorecard significantly influence firm value?; 2) Does Financial Performance significantly influence the firm value?; and 3) Does Corporate Social Responsibility Disclosure have a significant effect on firm value?

\section{LITERATURE REVIEW Signaling theory}

Signaling theory is a theory that discusses the ups and downs of prices in the market such as the prices of stocks, bonds, and so on, so that it will influence the investor's decision. Investors' responses to positive and negative signals are very influential in market conditions, they will react in various ways in responding to these signals. If the company gives a convincing signal to potential investors, investors will be interested and this will affect the price of the security.

According to Tandelilin (2010), this signal theory assumes that asymmetric information that occurs in the market causes it to have to make corrections of information by giving concrete actions and will clearly be captured as a signal that distinguishes it from others. The impact of a signal error will actually cause a negative response greater than a positive response when sending the wrong signal to the market.

\section{Agency Theory}

Jensen and Meckling (1976) state that an agency relationship is a contract between a manager (agent) and an investor (principal). There is a conflict of interest between the owner and agent because the possibility of the agent acting is not in accordance with the interests of the principal, thereby triggering agency costs. Conflict in agency theory is usually caused by decision makers who do not participate in taking risks as a result of decision making mistakes. According to decision makers, the risk should be borne by the shareholders. This is what causes the asynchronous between the decision maker (manager) with the shareholders. Conflicts between shareholders and company management can be minimized in a way, managers must run the company in accordance with the interests of shareholders as well as in making decisions by managers must be adjusted to the interests of shareholders (Wahyuni, 2013).

\section{Stakeholders Theory}

According to Clarkson (1995) in Hasian (2017), stakeholders are divided into two groups, namely primary and secondary. Primary stakeholders are groups of stakeholders who do not take part or participate in the operations of a company. Secondary stakeholders are groups of stakeholders who influence and are influenced by the company, but are not involved and are not so important for the survival of the company.

Stakeholder theory is a theory that states that a company is an entity that not only operates for its own interests, but must provide benefits to all its stakeholders, because the survival of a company is supported by stakeholders (Ghazali and Chariri, 2007 in Hasian, 2017) . Shareholders, creditors, consumers, suppliers, the government, the public, analysts, and other parties are stakeholder groups that are considered by the company to disclose or not reveal information in the company's financial statements. All stakeholders have the right to obtain information about company activities.

\section{Good Corporate Governance}

According to Keasy, Corporate governance is a structure, process, culture and system for creating successful operational conditions for an organization (Sunarto in Haris 2008 in Syukri and Chenny, 2018). Koesnohadi (in Haris 2008 in Syukri and Chenny, 2018) said that "Good Corporate Governance is a relationship among stakeholders that is used to determine and control the strategic direction and performance of the organization".

From the above understanding it can be concluded that Good Corporate Governance is a system of corporate governance in order to be better and can increase the value of the company by promoting fairness for all stakeholders, transparency regarding the condition of the company as part of the external environment. (Haris, 2008 in Syukri and Chenny, 2018)

The aim of Good Corporate Governance in general is to create added value for all interested parties, which explicitly by Global Corporate Governance is an important global issue. The Indonesian Institute for Corporate Governance (IICG) reveals the objectives of Good Corporate Governance:

1) Regain the confidence of investors and national and international creditors.

2) Meet the demands of global standards.

3) Minimizing the costs of losses and the costs of prevention of abuse of management authority.

4) Minimize the cost of capital by reducing the risk faced by creditors.

5) Increase the value of the company's shares.

6) Raise the company's image in the public eye.

The principles of Good corporate governance are:

1) Transparency (transparency)

2) Responsibility

3) Accountability

4) Professional (professional)

5) Fairness

According to the Corporate Governance in Indonesia (FCGI) Forum, there are several benefits that we can take from implementing good GCG, including:

1) Improve company performance through the creation of a better decision making process, 
improve company operational efficiency and further improve services to stakeholders.

2) Make it easier to obtain cheaper funding so that it can further enhance corporate value.

3) Restoring investor confidence to invest in Indonesia.

4) Shareholders will be satisfied with the company's performance because it will simultaneously increase shareholder value and dividends.

According to the Bassel Committee on Banking Supervision (BCBS) in Sari (2010 in Syukri and Chenny, 2018), the objectives and benefits of good corporate governance include the following:

1) Reducing agency costs, costs incurred due to abuse of authority, or in the form of supervision costs incurred to prevent a problem from arising.

2) Reducing capital costs arising from good management, which is able to minimize risk.

3) Maximizing the value of company shares, so as to improve the company's image in the eyes of the public in the long run.

4) Encouraging banking management in a professional, transparent, efficient and empowering functions and increasing the independence of the board of commissioners. Directors and GMS.

5) Encourage the board of commissioners, members of the board of directors, shareholders in making decisions and carrying out actions based on high morale and compliance with applicable laws.

6) Maintain the Going Concern of the company.

\section{Financial Performance}

Profitability is the ability of a bank to generate profits, both from operational activities and those from non-operational activities. Profitability is one of the factors considered in assessing whether a bank is healthy or not other than capital, asset quality, management and liquidity (Hafidz and Safira, 2018).

Profitability in this study was measured by Return On Assets (ROA). According to Brigham and Ehrhadrt (2005) in Praptiningsih (2009) ROA is the ratio of earnings before interest and taxes (EBIT) or net income divided by the book value of assets at the beginning of the fiscal year. Return on Assets measures the company's profits related to all disposal resources (shareholder capital plus short and long term borrowed funds). Therefore ROA is an excellent gauge in calculating the rate of return for shareholders. If the company has no debt, then the return on assets and return on equity will be the same. ROA measures how the profitability of a company is related to total assets. ROA provides an idea of how efficient management uses its assets to generate profits.

Based on Bank Indonesia Circular Letter No.13 / 24 / DPNP dated 25 October 2011 (Hafidz and Safira, 2018). Return On Assets can be calculated using the formula:

$$
R O A=\frac{\text { Profit before tax }}{\text { Total Asetts }}
$$

\section{Corporate Social Responsibility}

Corporate Social Responsibility is a concept that every organization especially a company has a social responsibility to all its stakeholders. Where there are consumers, employees, shareholders, communities and the environment in all aspects of the company's operations that include economic, social and environmental aspects.

Porter and Kramer (2006) identified four reasons for companies to engage in social responsibility. First, the public in general and companies in particular, believe that the company has a moral obligation to engage in actions for the benefit of various parties, whether this action is beneficial. Both concepts of sustainability emphasize the need for company management from the environment and society. Third is the legitimacy to operate from the government, the community, to conduct business activities. The four socially responsible can increase the reputation of the company.

Corporate social responsibility disclosure is measured by CSRI (corporate social responsibility index) proxy based on CSR Disclosure indicators guided by the fourth generation Global Reporting Initiative (GRI) or called G4 with 91 CSR disclosure indexes. Information on Corporate Social Responsibility based on GRI 4 consists of 3 disclosure focuses, namely social, economic, and environmental (Heryanto \& Julianto, 2017).

\section{Firm Value}

Firm value is the investor's perception of the company, which is often associated with stock prices. High stock prices make the value of the company is also high. Firm value is commonly indicated by price to book value. A high price to book value will make the market believe in the company's future prospects. This is also the desire of the owners of the company, because high company values indicate the prosperity of shareholders is also high (Lidenberg and Ross, 1981).

Some company performance indicators that can be used to look at company performance such as market performance (Tobin's Q) are indicators to measure the Firm value, which shows a market performance that will be responded by investors. Tobin's $Q$ value describes a condition of investment opportunities that the company has or the company's growth potential (Fiakas, 2005). Tobin's Q value is generated from the sum of the market value of shares (debt value of all debt) compared to the value of all capital placed in production assets (replacement value of all production capacity), then Tobin's Q can be used to measure the value of the company, namely in terms of potential value market of a company.

Tobins' $\mathrm{Q}$ in its application has been modified, as used in this study in reference to Fiakas, (2005); Bhagat and Bolton (2008) have been used consistently. Tobin's Q $<1$ illustrates that the stock is undervalued. Management has failed in managing the company's assets, this shows the potential for low investment growth. Tobin's $Q=1$ illustrates that 
stocks are in average condition, meaning that management is stagnant in managing assets, which shows the potential for investment growth to not develop. Tobin's $\mathrm{Q}>1$ illustrates that stocks in an overvalued condition means that management is successful in managing assets, this shows the potential for high investment growth.

\section{Prior Research}

Previous research that can support this research is as follows: Safira \& Saifi (2019) in his research entitled "The Effect of Corporate Social Responsibility (CSR) on Company Value and Financial Performance". The results of this study conclude that (1) Corporate Social Responsibility (CSR) is significantly significant in terms of the value of the business; (2) Corporate Social Responsibility (CSR) is significantly significant in terms of performance; and (3) the value of the destruction has a significant effect on the performance.

Adhiprasetya and Zulaikha (2019) in their research entitled "The Effect of Corporate Governance Perception Index on Company Value and Corporate Financial Performance". The results showed that the Corporate Governance Perception Index variable had no significant effect on firm value, but had a significant effect on the company's financial performance.

Mukhtaruddin et al. (2019) in his research entitled "Good Corporate Governance, Corporate
Social Responsibility, Firm Value, and Financial Performance as Moderating Variables". The results showed that (1) Good corporate governance has a positive effect that is not significant to the value of the company; (2) Corporate social responsibility has a significant negative impact on company value; and Financial performance has significantly strengthened the relationship between good corporate governance and corporate social responsibility on corporate value.

Wati et al. (2019) in his research entitled "The Role of CSR Disclosure and GCG Mechanisms on Financial Performance Against Company Value". The results showed that the company's financial performance had a significant effect on firm value. CSR disclosure is able to moderate the relationship between financial performance and firm value, but managerial ownership as a GCG mechanism is not able to moderate the relationship between performance and firm value. CSR can build a positive image of the company in the eyes of investors and the public, because by disclosing social information will attract investors and have an impact on increasing the value of the company.

\section{Thought Framework}

Based on the theoretical foundation and previous studies, the researcher develops the research framework tested as shown in the following figure:

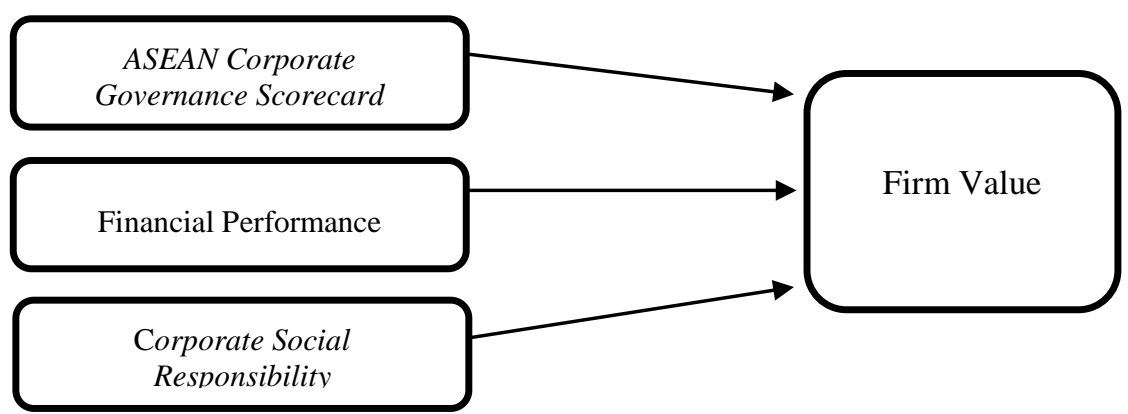

Figure 1.1 Framework for Thinking

\section{Hypothesis} follows:

The research hypotheses proposed are as

Ha1: ASEAN Corporate Governance Scorecard has a positive effect on Firm Value

Ha2: Financial Performance has a positive effect on Firm Value

Ha3: Disclosure of corporate social responsibility has a positive effect on Firm Value

\section{RESEARCH METHOD Types of research}

The research used in this study is casual associative research (causal associative research). According to Sanusi (2011), associative-causal research is a research that seeks a relationship between two or more variables. The purpose of associative research is to look for relationships between one variable and another.

\section{Definition of Variable Operations}

Operational research variables on the ASEAN Corporate Governance Scorecard, Profitability, and Corporate Social Responsibility Disclosure of Firm Value can be summarized in the following table: 
Table 1.1 Operasionalisasi Variabel

\begin{tabular}{|c|c|c|c|}
\hline $\begin{array}{c}\text { Variable } \\
\text { Type }\end{array}$ & Operational definition & Measurement & Scale \\
\hline \multicolumn{4}{|l|}{ Dependent } \\
\hline Firm Value & $\begin{array}{l}\text { Market-based company } \\
\text { performance }\end{array}$ & Adjusted Tobin's Q & Ratio \\
\hline \multicolumn{4}{|l|}{ Independent } \\
\hline $\begin{array}{l}\text { ASEAN } \\
\text { Corporate } \\
\text { Governance } \\
\text { Scorecard }\end{array}$ & $\begin{array}{l}\text { An initiative of the ACMF } \\
\text { (ASEAN Capital Market Forum) } \\
\text { to provide guidelines for the } \\
\text { implementation of good } \\
\text { corporate governance in ASEAN } \\
\text { member countries }\end{array}$ & $\begin{array}{c}\text { ASEAN Corporate } \\
\text { Governance Scorecard } \\
\text { Rating } \\
\text { taken from research and } \\
\text { assessment programs } \\
\text { conducted by ACMF (ASEAN } \\
\text { Capital Market Forum) } \\
\end{array}$ & Score \\
\hline $\begin{array}{l}\text { Financial } \\
\text { Performance }\end{array}$ & $\begin{array}{l}\text { The ability of a bank to generate } \\
\text { profits, both from operational } \\
\text { activities and from non- } \\
\text { operational activities. }\end{array}$ & ROA & Ratio \\
\hline $\begin{array}{l}\text { Disclosure of } \\
\text { Corporate } \\
\text { Social } \\
\text { Responsibilit } \\
\text { y }\end{array}$ & $\begin{array}{l}\text { Mechanisms for an organization to } \\
\text { voluntarily integrate environmental } \\
\text { and social attention into its } \\
\text { operations and interactions with } \\
\text { stockholders, which exceeds } \\
\text { organizational responsibility in the } \\
\text { legal field. }\end{array}$ & $\frac{\sum \text { Skor }}{\text { Skor Maks }}$ & Ratio \\
\hline
\end{tabular}

\section{Data Types and Sources}

The data used in conducting this research is secondary data, that is data obtained through intermediaries from both parties and certain media that support this research. The data used in this study are secondary data in the form of company financial statements which included 50 TOP ASEAN Corporate Governance Scorecards during the 20152017 period obtained from the Indonesia Stock Exchange website (www.idx.co.id) and the official website of each company the.

\section{Population and Research Samples}

The population in this study were all companies that included 50 TOP ASEAN Corporate Governance Scorecards during the 2015-2017 period. The sampling technique is using purposive sampling technique. According to Widyani (2010) the purposive sampling method is the selection of samples on the basis of the suitability of the characteristics of the sample with the specified sample selection criteria. The sample in this study were companies that included 50 TOP ASEAN Corporate Governance Scorecards during the 20152017 period that met predetermined research criteria. The sample criteria used in this study are:

1) Companies included in the TOP 50 ASEAN Corporate Governance Scorecards during the 2015-2017 period.

2) Publish audited financial statements for the period of 2015-2017.

3) Companies that use the rupiah value unit in their financial statements.
4) The company did not experience a loss during the study year.

5) Data owned by the company is complete and in accordance with the variables studied.

According to the criteria above, the number of samples of companies used were 27 companies over 3 periods, namely 2015, 2016 and 2017. Then the number of samples obtained was 27 companies x 3 periods $=81$ data that will be used in this study.

\section{Data collection technique}

Data collection methods in this research are literature study and documentation methods. Literature study method by studying literature and reviewing a variety of literature literature such as various journals, articles and other literature books that support the research process. While the documentation method is the process of collecting data by recording documents related to this research.

\section{Analysis Method}

\section{Descriptive statistics}

Descriptive statistics in this study are used to provide a description of the character of the research variable using a frequency distribution table that shows the mode number, the range of scores and the standard of division

\section{Classic assumption test}

This research was conducted with a simple regression analysis. The use of simple regression analysis must be free from testing classic assumptions. For this reason, before a simple 
regression analysis is required, classical assumptions must be tested first. Testing classic assumptions is done using normality test, multicollinearity test, heterokedasticity test and autocorrelation test.

\section{Hypothesis testing}

In this study the authors used three independent variables and one dependent variable. The analytical method used to test hypotheses is the multiple regression method, which is regression used to find out how much influence the independent variable has on the dependent variable. Regression analysis using SPSS software version 25 . The regression equation is as follows: $Y=\alpha+\beta_{1} X_{1}+\beta_{2} X_{2}+\beta_{3} X_{3}+\varepsilon$

Where :

$$
\begin{aligned}
\mathrm{Y}= & \text { Firm Value } \\
\alpha= & \text { constant or price } \mathrm{Y} \text { if } \mathrm{X}=0 \\
\beta= & \text { number or direction of the regression } \\
& \begin{array}{l}
\text { coefficient, which indicates an increase or } \\
\text { decrease in the dependent variable based on }
\end{array} \\
& \text { the independent variable } \\
\mathrm{X} 1= & \text { ASEAN Corporate Governance Scorecard } \\
& \text { (ACGS) } \\
\mathrm{X} 2= & \text { Profitability }
\end{aligned}
$$

\section{$\mathrm{X} 3=$ Disclosure of Corporate Social Responsibility \\ $\varepsilon=$ level of disturbing error / error}

In this study, the significance level $(\alpha)$ of 0.05 or $5 \%$ was used. To test whether the proposed hypothesis is accepted or rejected, a test of the research variables is carried out by simultaneously testing through the simultaneous significance test $(\mathrm{F}$ statistic test), which intends to explain the effect of the independent variable on the dependent variable. Meanwhile, to test each variable partially, it is carried out by means of an individual parameter significance test (statistical $t$ test) which aims to find out whether the independent variable influences the dependent variable, and which of the dominant variables influences the dependent variable.

\section{RESEARCH RESULTS AND DISCUSSION}

\section{Research Data Description}

The following are descriptive statistical results about the research variables as follows:

Table 1.2 Descriptive statistical results

\begin{tabular}{|l|c|c|c|c|c|}
\hline \multicolumn{1}{|c|}{ Variable } & N & Min & Max & Mean & $\begin{array}{c}\text { Std. } \\
\text { Deviation }\end{array}$ \\
\hline ASEAN CG Scorecard & 81 & 65,44 & 96,17 & 79,86 & 6,935 \\
\hline Financial Performance & 81 & 0,00 & 0,58 & 0,10 & 0,135 \\
\hline CSR & 81 & 0,18 & 0,81 & 0,39 & 0,149 \\
\hline Firm Value & 81 & 0,53 & 23,29 & 2,97 & 4,623 \\
\hline
\end{tabular}

Based on Table 1.2 above, it can be presented descriptive statistical results about the research variables as follows: The average value of the ASEAN Corporate Governance Scorecard variable is $79.86 \%$ with a standard deviation value of $6.935 \%$, this shows that the data used is highly fluctuating from in 2015 to 2017. The ASEAN Corporate Governance Scorecard variable ranges from the lowest value of $65.44 \%$, namely PT Bank CIMB Niaga Tbk in 2017 to the highest value of $65.44 \%$, namely PT Wijaya Karya (Persero) Tbk in 2015.

The average value of the Financial Performance Variable measured by Return on Assets (ROA) is 0.10 or $10 \%$, with a standard deviation of 0.135 or $13.5 \%$, which means the data used is highly fluctuating from 2015 to 2017. Profitability Variables ranging from the lowest value of $0.00(0 \%)$, namely PT Bank CIMB Niaga Tbk in 2015 to the highest value of 0.58 (58\%), namely PT Matahari Department Store Tbk in 2015. The average value of profitability was 0.10 indicates that for every Rp 1 of the funds invested by investors as share capital, will generate a net profit of $10 \%$.
Corporate Social Responsibility Disclosure Variables have an average of 0.39 or $39 \%$ with a standard deviation value of 0.149 or $14.9 \%$, this shows that the data used is highly fluctuating from 2015 to 2017. Corporate Social Responsibility Disclosure Variables range from the lowest value of 0.18 or $18 \%$, namely PT Wijaya Karya (Persero) Tbk in 2017 up to the highest value of 0.81 or $81 \%$, namely PT Tambang Batubara Bukit Asam (Persero) Tbk in 2016.

The average value of the Company Value Variable is 2.97 with a standard deviation value of 4.623, which means the data used is highly fluctuating from 2015 to 2017 . The Company Value variable ranges from the lowest value of 0.53 , namely PT Saratoga Investama Sedaya Tbk in 2017 up to the highest value of 23.29, namely the company PT Unilever Indonesia Tbk in 2017.

\section{Classic Assumption Test Normality test}

Testing for normality using the Lilliefors test. Provisions in the error test are if the statistic L count $<$ L table $(\alpha=0.05)$, then the error data is normally 
distributed. But if $\mathrm{L}$ count $>\mathrm{L}$ table $(\alpha=0.05)$, then the data is not normally distributed.
Thus the overall results of the normality test calculation using the Lilliefors test can be seen in the summary in Table 1.3 .

Table 1.3 Normality Test Summary

\begin{tabular}{|c|c|c|c|c|c|c|}
\hline \multirow{2}{*}{ No } & \multirow{2}{*}{ Estimation } & \multirow{2}{*}{$\mathrm{n}$} & \multirow{2}{*}{$\mathrm{L}_{\text {Count }}$} & \multicolumn{2}{|c|}{$\mathrm{L}_{\text {Table }}$} & \multirow{2}{*}{ Decision } \\
\cline { 5 - 6 } & & & & $\alpha=0,05$ & $\alpha=0.01$ & \\
\hline 1 & Y atas X1 & 81 & $-0,1699$ & 0,0984 & 0,1146 & Normal \\
\hline 2 & Y atas X2 & 81 & $-0,1015$ & 0,0984 & 0,1146 & Normal \\
\hline 3 & Y atas X3 & 81 & $-0,1665$ & 0,0984 & 0,1146 & Normal \\
\hline
\end{tabular}

\section{Multicollinearity Test}

Multicollinearity Test aims to test whether in a regression model found a correlation between independent variables. A good regression model should not occur correlation between independent variables (Ghozali, 2010). Detection of the presence or absence of multicollinearity in this study by (1) analyzing the correlation matrix between independent variables, if there is a high enough correlation between independent variables (generally above 0.90 ), then this is an indication of multicollinearity, (2) Looking at the value tolerance and the value of the variance inflation factor, a regression model that is free from multicollinearity problems if it has a tolerance value of more than 0.10 or $10 \%$ and the value of the variance inflation factor (VIF) is less than 10. The results of accounting tolerance according to Table 1.4. shows that there are no independent variables that have a tolerance value of less than $10 \%$; all tolerance values are more than $10 \%$; which means there is no correlation between variables. The results of the calculation of the variance inflation factor (VIF) value also show the same thing, there are no independent variables that have a VIF value of more than 10; the values of the variance inflation factor (VIF) are all less than 10. The conclusion is that there is no multicollinearity between independent variables in the regression model based on the tolerance value test.

Table 1.4 Multicolonierity Test Summary

\begin{tabular}{|l|c|c|}
\hline \multirow{2}{*}{ Variable } & \multicolumn{2}{c|}{ Collinearity Statistics } \\
\cline { 2 - 3 } & Tolerance & VIF \\
\hline ASEAN CG Scorecard & 0,938 & 1,067 \\
\hline Profitability & 0,952 & 1,051 \\
\hline CSR & 0,985 & 1,016 \\
\hline
\end{tabular}

Source: Primary data processed (2020)

\section{Autocorrelation Test}

Autocorrelation test is used to determine whether there is a correlation between a fault in a certain period with a mistake in the previous period. A good regression model is a regression that is free from autocorrelation. Autocorrelation test can be done by testing the Durbin-Watson (DW). The autocorrelation test results can be seen in Table 1.5 below:

Table 1.5 Autocorrelation test Results

\begin{tabular}{|c|c|c|c|c|c|}
\hline Model & R & R Square & $\begin{array}{c}\text { Adjusted R } \\
\text { Square }\end{array}$ & $\begin{array}{c}\text { Std. Error of } \\
\text { the Estimate }\end{array}$ & Durbin-Watson \\
\hline 1 & $0,795^{\mathrm{a}}$ & 0,632 & 0,618 & 2,859 & 1,960 \\
\hline
\end{tabular}

Based on SPSS output, the Durbin Watson statistical value is 1,960 . While from the Durbin Watson table with $\mathrm{n}=81$ and $\mathrm{k}=3$, the $\mathrm{d}$ table is obtained ie $\mathrm{dl}$ (outer boundary) $=1.563$ and du (inner limit) $=1.716$ with a significance level of $5 \%, 4-d u=$ 2.284 ; and $4-\mathrm{dl}=2,437$; then from accounting it is concluded that the DW-test is located in the test area. Referring to Ghozali (2010), the regression model in this study is free from the autocorrelation problem because the Durbin Watson value is between du and 4 du.

\section{Heteroscedasticity Test}

Heterokedastisitas test is used to determine whether or not there is a deviation from the classic assumption of heterokedasticity, that is, the variance of the residual inequality for all observations in the regression model (Priyatno, 2009). Detection of heterokedastisitas are: 1) Probability value $>0.05$ 
means free from heterokedastisitas. 2) Probability value $<0.05$ means it is exposed to heterokedasticity.
The test results using the Spearman rank test can be seen in the following Table 1.6:

Table 1.6 Heterokedastisity test Results

\begin{tabular}{|l|l|l|c|c|c|}
\hline \multirow{2}{|c|}{ Spearman's rho } & $\begin{array}{l}\text { Absre } \\
\text { s }\end{array}$ & $\begin{array}{l}\text { Correlation } \\
\text { Coefficient }\end{array}$ & $-0,131$ & 0,552 & 0,137 \\
\cline { 2 - 6 } & & Sig. (2-tailed) & 0,243 & 0,098 & 0,223 \\
\cline { 2 - 6 } & $\mathrm{N}$ & 81 & 81 & 81 \\
\hline
\end{tabular}

Spearman rank test results in the table above shows the value of the probability of significance for the variable profitability, capital structure, and sales growth of $0.243 ; 0.098$; and 0.223 . Because the probability value of significance for the ASEAN Corporate Governance Scorecard, Financial Performance, and CSR Disclosures is greater than 0.05 , it can be concluded that the data are free from heterokedastisitas.

\section{Hypothesis test Multiple regression analysis}

Multiple regression analysis is used to get the regression coefficient which will determine whether the hypothesis made will be accepted or rejected. By using multiple linear regression methods the following results are obtained:

Table 1.7 Regression analysis Results

\begin{tabular}{|c|c|c|c|c|c|c|c|c|}
\hline & Model & B & $\mathbf{T}_{\text {count }}$ & Sig & $\mathbf{T}_{\text {table }}$ & $\operatorname{adj} \mathrm{R}^{2}$ & $F_{\text {count }}$ & Sig \\
\hline \multirow{4}{*}{1} & $\begin{array}{c}\text { (Constant } \\
\text { ) }\end{array}$ & $-3,899$ & & & \multirow{4}{*}{1,665} & \multirow{4}{*}{0,618} & \multirow{4}{*}{44,053} & \multirow{4}{*}{0,000} \\
\hline & $\mathrm{X} 1$ & 0,063 & 1,326 & 0,189 & & & & \\
\hline & $\mathrm{X} 2$ & 27,662 & 11,376 & 0,000 & & & & \\
\hline & X3 & $-2,566$ & $-1,185$ & 0,240 & & & & \\
\hline
\end{tabular}

Source: Primary data processed (2020)

Based on the results of the regression tests above, an equation can be formed as follows: $\mathrm{Y}=$ $3,899+0,063 X_{1}+27,662 X_{2}-2,566 X_{3}+\varepsilon$

\section{Determination Coefficient Test $\left(\mathbf{R}^{2}\right)$}

The coefficient of determination shown by the adjusted R Square value. The adjusted R-Square value of the regression model is used to find out how much the ability of the independent variable in explaining the dependent variable. From Table 1.7 it is known that the adjusted $\mathrm{R}$ square value is 0.618 . This means that $61.8 \%$ of the company's value can be explained by variations in independent variables namely the ASEAN Corporate Governance Scorecard, Financial Performance, and CSR Disclosures, the remaining $38.2 \%(100 \%-61.8 \%)$ is explained by other causes in outside the model.

\section{Simultaneous Significance Test (Statistical Test F)}

Simultaneous significance test (Test F) is used to show whether all the independent variables entered in the model have an influence together on the dependent variable. (Ghozali, 2009). If the analysis using the $\mathrm{F}$ test shows that all the independent variables simultaneously are an explanatory significance of the dependent variable.

From the Anova test or the F test in Table 1.7 above, the $F$ count value is 44,053 with a significance probability that indicates 0,000 . Test probability values are much smaller than $\alpha=0.05$. This shows that together (simultaneously) the value of the company can be influenced by the ASEAN Corporate Governance Scorecard variable, Financial Performance, and CSR Disclosure.

\section{Significance Test of Individual \\ Parameters (t Test) \\ Effect of the ASEAN Corporate}

Governance Scorcard on firm value

Based on the accounting results in table 1.7 above shows that the ASEAN Corporate Governance Scorecard variable has no effect on firm value, which can be seen from the comparison between ttable and tcount, ie ttable is greater than tcount, with a ttable value of 1.665 and tcount 1.326 and a significance level located above 0.05 . Thus $\mathrm{Ha} 2$ rejected.

\section{Effect of Financial Performance on firm} value

Based on the accounting results in table 1.7 above shows that the financial performance variable has a positive effect on firm value, which can be seen from the comparison between ttable and tcount, ie ttable is smaller than tcount, with ttable value 1,665 and tcount 11,376 and the level of significance is much smaller than 0.5 . Thus $\mathrm{Ha} 2$ received. 


\section{Effect of corporate social responsibility disclosure on firm value}

Based on the accounting results in table 1.7 above shows that the disclosure variable Corporate Social Responsibility does not affect the firm value, which can be seen from the comparison between ttable and tcount, ie ttable is greater than tcount, with a ttable value of 1,665 and tcount $-1,185$ and the level of significance is far greater than 0.05 . Thus Ha3 was rejected.

\section{DISCUSSION \\ Effect of the ASEAN Corporate \\ Governance Scorecard on firm value}

From the results of the study note that the ASEAN Corporate Governance Scorecard variable does not affect the firm value in a positive direction. So it can be stated that the higher the ACGS score the higher the company value. The ineffectiveness of the ASEAN Corporate Governance Scorecard on firm value is due to the fact that the implementation of good corporate governance is felt by companies going public as a demand for existing regulations, not as an important requirement for companies, so there is a lack of awareness of these companies to implementing good corporate governance.

In addition, companies that go public in Indonesia only implemented good corporate governance after the economic crisis that hit Indonesia in 1997, whereas the implementation of good corporate governance cannot be done directly or in the short term, because implementing good corporate governance requires time, planning, and information about characteristics, culture, and relationships between company organs. For example, there are companies who think that transparency means disclosing important company secrets to outsiders, which will threaten the company's presence in selling its products and services.

The results of this study support the findings of Adhiprasetya \& Zulaikha (2019), which shows that the ranking of the Corporate Governance Perception Index (CGPI) has no significant effect on firm value. However, the results of this study are not in line with research conducted by Halim \& Christiawan (2017) which states that the Corporate Governance Perception Index (CGPI) has a significant impact on company performance.

\section{Effect of financial performance on firm value}

From the results of the study note that financial performance as measured by Return on Assets affect the firm value. Significant influence between profitability on firm value due to the large profitability of a company becomes a reference point for investors in valuing a company. While the positive effect between the level of profitability on the value of the company is due to the higher profitability of a company, it shows a good prospect of the company so that investors will respond positively to these signals and the value of the company will increase.

Companies need to pay attention and continue to improve ROA by increasing profits. ROA results state that the company produces in favorable conditions, so if the ROA is high it will give a positive signal to investors. This is an attraction for investors to own company shares. High stock demand will directly increase the value of the company. Thus financial performance has a positive and significant effect on firm value.

These results support research conducted by Leonardo \& Khairunnisa (2019), and Susanti, et al (2019) which states that financial performance has a significant positive effect on firm value. However, the results of this study are not in line with research conducted by Lutfia, et al (2019), Lastanti \& Salim (2019) found that financial performance has no effect on firm value.

\section{Effect of corporate social responsibility disclosure on firm value}

From the results of the study note that the variable Corporate Social Responsibility disclosure does not affect the firm value with a negative direction. The absence of disclosure of Corporate Social Responsibility to the firm value, due to the disclosure of Corporate Social Responsibility in companies that are included in the 50 TOP ASEAN Corporate Governance Scorecard tends to be stable, while the value of the company as measured by Tobin's $Q$ indicates an increase and decrease. This shows that the increase or decrease in the value of the company is not influenced by the value of CSR. Shareholders do not pay much attention to CSR activities carried out by the company. Another cause is that in Indonesia CSR activities are still new, this is evidenced by the Law on CSR recently issued by the government in 2007, namely Law No. 40 of 2007 Article 74 concerning Social and Environmental Responsibility of Limited Liability Companies so that CSR reporting has not been respected by investors.

The results of this study are supported by research by Sumantri \& Andini (2019) finding that disclosure of Corporate Social Responsibility has no effect on firm value. However, the results of this study are not in line with research conducted by Mukhtaruddin et al. (2019), and Safira \& Saifi (2019) found that the disclosure of Corporate Social Responsibility affects the firm value.

\section{CONCLUSION}

Based on the results of the analysis and discussion carried out, the following conclusions can be drawn: 1) The ASEAN Corporate Governance Scorecard variable does not affect the firm value in a positive direction; 2) Financial Performance variable has a positive effect on firm value; 3) Variable 
disclosure of Corporate Social Responsibility does not affect the firm value with a negative direction.

\section{Limitation}

This research is inseparable from the shortcomings and limitations. Limitations in this study are as follows: 1) Companies that are sampled in this study have not included all the countries in ASEAN that are included in the ASEAN scorecard measurement, so they do not reflect the overall performance of ASEAN companies; 2) The observation period is limited during 2015-2017.

\section{Suggestions}

As explained earlier that this study contains limitations. But the results of this study can at least motivate further research. Considering the existing limitations, it is expected that future research will improve the following factors: 1) In subsequent studies, the following research will include all countries included in the ASEAN Corporate Governance Scorecard, namely Indonesia, Malaysia, the Philippines, Thailand, and Vietnam; 2) To obtain better research results, further research can extend the research period.

\section{REFERENCES}

1. Adi Suharna dan Fifi Swandari. (2013). Pengaruh Corporate Governance Perception Index Terhadap Kinerja perusahaan dalam Masa Krisis Ekonomi Global. Jurnal Wawasan Manajemen. Vol. 1, Nomor 1, Februari

2. Ainy, R., N., \& Barokah, Z. (2019). Corporate Governance, Environmental Responsibility and Firm Value: An Empirical Study in Indonesia and Malaysia. Journal of Accounting and Investment. Vol. 20, No. 2

3. Alshammari M. (2015). Corporate Social Responsibility and Firm Performance: The Moderating Role of Reputation and Institutional Investors. International Journal o Business and Management. Vol. 10, No. 6

4. Alvian Adhiprasetya dan Zulaikha. (2019). Pengaruh Corporate Governance Perception Index Terhadap Nilai Perusahaan dan Kinerja Keuangan Perusahaan. Diponegoro Journal of Accounting. Vol. 8, No. 4

5. Anderson, M. L, dan Olsen, L. (2011). Corporate Social and Financial Performance: A Canonical Correlation Analysis. Academy of Accounting and Financial Studies Journal. Vol. 15, No. 2

6. Astri Aprianingsih, dan Amanita Novi Yushita. (2016). Pengaruh Penerapan Good Corporate Governance, Struktur Kepemilikan, dan Ukuran Perusahaan Terhadap Kinerja Keuangan Perbankan. PROFITA. Vol. 4, No. 4

7. Bhatt, P. R., \& Bhatt, R. R. (2017). Corporate governance and firm performance in Malaysia. The International Journal of Business in Society. Vol. 17, No. 5

8. Citra Lutfia, Widi Hidayat, dan Frida Fanani Rohma. (2019). Determinan Nilai Perusahaan: Apakah Peran Pengungkapan Tanggungjawab Sosial?. Jurnal TECHNOBIZ. Vol. 3, No. 2
9. Giovani, D. E., \& Mulyana, R. A. (2017). Pengaruh Good Corporate Governance Terhadap Company Performance Pada Perusahaan Manufaktur di Indonesia dan Thailand. Jurnal Bisnis dan Akuntansi. Vol. 19, No. 1

10. Hafidz Ridho Ansori dan Safira. (2018). Analisis Pengaruh Manajemen Risiko Terhadap Profitabilitas (Studi Komparatif Pada Bank Umum Konvensional dan Bank Umum Syariah yang Terdaftar di OJK Periode 2012-2015). Jurnal Profita. Vol. 11. No. 1. April.

11. Helda Safira dan Muhammad Saifi. (2019). Pengaruh Corporate Social Responsibility (CSR) Terhadap Nilai Perusahaan dan Kinerja Keuangan”. Jurnal Administrasi Bisnis (JAB). Vol. 76, No. 1 November

12. Helga Adeline Halim dan Yulius Jogi Christiawan. (2017). Pengaruh Penerapan Corporate Governance Terhadap Nilai Perusahaan dengan Ukuran Perusahaan dan Umur Perusahaan Sebagai Variabel Kontrol. Business Accounting Review. Vol. 5, No. 2, Agustus

13. Hexana Sri Lastanti dan Nabil Salim. (2018). Pengaruh Pengungkapan Corporate Social Responsibility, Good Corporate Governance, dan Kinerja Keuangan Terhadap Nilai Perusahaan. Jurnal Akuntansi Trisakti. Vol. 5, No. 1 Februari

14. IICD. (2014). Press Release Top 50 Emiten dengan Skor Terbaik berdasarkan ASEAN CG Scorcard.

15. Imam Ghozali. (2011). Aplikasi Analisis Multivariate dengan Program IBM SPSS 19. Semarang: Badan Penerbit Universitas Diponegoro.

16. Kasmir. (2014). Bank dan Lembaga Keuangan Lainnya. Yogyakarta : Rajawali Pers

17. Lela Nurlaela Wati, Galang Raindo Syahdam, dan Bono Prambudi. (2019). Peran Pengungkapan CSR Dan Mekanisme GCG Pada Kinerja Keuangan Terhadap Nilai Perusahaan. Jurnal Ecodemica. Vol. 3, No. 2 September

18. Leonardo dan Khairunnisa. (2019). Pengaruh Kinerja Keuangan Terhadap Nilai Perusahaan (Studi Pada Perusahaan Pertambangan di Sub Sektor Pertambangan Batu Bara Yang Terdaftar di Bursa Efek Indonesia Periode 2013-2017). eProceeding of Management. Vol. 6, No. 2 Agustus

19. Mukhtaruddin, M., Ubaidillah, U., Dewi, K., Hakiki, A., \& Nopriyanto, N. (2019). Good Corporate Governance, Corporate Social Responsibility, Firm Value, and Financial Performance as Moderating Variable. Indonesian Journal of Sustainability Accounting and Management. Vol. 3, No. 1

20. Munawir. (2010). Analisa Laporan Keuangan. Edisi keempat. Yogyakarta: Liberty

21. Novi Syiti Masitoh dan Nurul Hidayah. (2018). Pengaruh Penerapan Good Corporate Governance Terhadap Kinerja Perusahaan (Studi Empirik Pada Perusahaan Perbankan di BEI tahun 2014-2016). Jurnal Tekun. Vol 1. No. 1.

22. Owusu, A., \& Weir, C. (2016). The GovernancePerformance Relationship: Evidence from 
Ghana. Journal of Applied Accounting Research. Vol. 17, No. 3

23. Shafie Mohamed Zabri; Kamilah Ahmad; and Khaw Khai Wah. (2016). Corporate Governance Practices and Firm Performance: Evidence from Top 100 Public Listed Companies in Malaysia. Procedia Economics and Finance. Vol. 7, No. 35

24. Sudershan Kuntluru. (2019). Impact of Corporate Governance Disclosures on Firm Performance. Working Paper Indian Institute of Management Kozhikode

25. Sumatriani. (2017). ASEAN Corporate Governance Scorecard, Kinerja Keuangan, Pengungkapan Tanggung Jawab Sosial Terhadap Nilai Perusahaan. Disertasi Fakultas Ekonomi dan Bisnis Universitas Hasanuddin Makassar.

26. Susanti Widhiastuti, Eftianto, dan Slamet Ahmadi. (2019). Pengaruh Kinerja Keuangan Terhadap Nilai Perusahaan yang Dimediasi oleh Pengungkapan Sustainability Report. Jurnal Ilmiah Akuntansi dan Keuangan. Vol.08, No.02

27. Syukri Hadi, Fadrul, dan Chenny Juny Luvita. (2018). Pengaruh Good Corporate Governance terhadap Kinerja Perusahaan Perbankan yang terdaftar di Bursa Efek Indonesia pada Tahun 2012-2016. BILANCIA. Vol. 2 No. 4, Desember 